\title{
COUP-TFII Knock-down Promotes Proliferation and Invasion in Colorectal Cancer Cells via Activation of Akt Pathway and Up-regulation of FOXC1
}

\author{
SEONG-HOON YUN*, SANG-HEUM HAN* and JOO-IN PARK \\ Department of Biochemistry, Dong-A University College of Medicine, Busan, Republic of Korea
}

\begin{abstract}
Background/Aim: The chicken ovalbumin upstream promoter-transcription factor II (COUP-TFII) regulates cancer cell proliferation and invasion via complex molecular mechanisms. We aimed to investigate whether COUP-TFII modulates proliferation and invasion of the colorectal adenocarcinoma cell line HT-29. Materials and Methods: HT-29 cells were stably tranfected with COUPTFII shRNA plasmid to knock-down COUP-TFII (COUPTFII shRNA-HT-29 cells). Cell proliferation, colony formation assay, invasion assay, microarray assays and western blot analyses were performed. Results: Cell proliferation and invasion were significantly enhanced in COUP-TFII shRNA-HT-29 cells. The protein levels of forkhead box Cl (FOXC1), p-Akt, p-glycogen synthase kinase- $3 \beta(p-G S K-3 \beta)$, and $\beta$-catenin, which are known to be involved in cell proliferation and invasion, were significantly increased in COUP-TFII shRNA-HT-29 cells. Akt inhibitor IV and dominant negative (DN)-Akt expression vector transfection reversed the increased proliferation and invasion, which was accompanied by decreased protein levels of $p$-Akt, $p$-GSK-3 $\beta, \beta$-catenin and FOXC1. Conclusion: COUP-TFII knock-down promoted proliferation and invasion via activation of Akt/GSK-3 $\beta / \beta$-catenin and upregulation of FOXC1. Further studies on the molecular mechanism of interaction between $\beta$-catenin and FOXC1 expression may reveal novel target molecules for metastatic colorectal cancer therapy.
\end{abstract}

*These Authors contributed equally to this study.

Correspondence to: Joo-In Park, MD, Ph.D., Department of Biochemistry, Dong-A University College of Medicine, Busan 49201, Republic of Korea. Tel: +82 512402881, e-mail: jipark@dau.ac.kr

Key Words: Chicken ovalbumin upstream promoter-transcription factor II (COUP-TFII), colorectal cancer, Akt, $\beta$-catenin, forkhead box $\mathrm{C} 1$ (FOXC1).
Colorectal cancer (CRC) is one of the most common causes of cancer-related deaths worldwide $(1,2)$. The incidence of $\mathrm{CRC}$ is rapidly growing in Asian countries, with rates similar to that of Western countries $(3,4)$. Cancer metastasis, which accounts for about $90 \%$ of cancer deaths, is the critical unresolved challenge underlying cancer morbidity and mortality (5). In addition, $80 \%$ of the first diagnosed metastatic colon cancer patients do not survive for more than five years (6). Thus, a better insight into the underlying mechanisms of tumor metastasis is necessary to improve the survival rate of metastatic CRC.

The orphan nuclear receptor chicken ovalbumin upstream promoter-transcription factor II (COUP-TFII) belongs to the superfamily of steroid/thyroid hormone receptors with highly conserved motifs (7). It regulates various biological processes, including organ development, cell fate determination, and gene expression (8). Recent reports have shown that COUP-TFII significantly contributes to the regulation of metabolism and angiogenesis in metastasis, tumor progression, and tumor formation (9). Evidence suggests that COUP-TFII promotes tumor progression by enhancing cell proliferation and invasion $(10,11)$. However, COUP-TFII has also been reported to act as a tumor suppressor. For example, overexpression of COUP-TFII in breast cancer cell lines leads to increased expression of cyclin D1 and p21, resulting in reduced cell growth and plating efficiency (12). In line with this, expression of COUP-TFII has been shown to be reduced in human gastric cancer cells compared to normal cells (13). In addition, ectopic expression of COUP-TFII is reported to inhibit liver metastasis in vivo, as well as cell proliferation, migration and invasion in vitro (13). Our previous studies showed that COUP-TFII is a good prognostic factor in CRC patients (14, 15). Thus, further investigation into the role of COUP-TFII in CRC is required.

Forkhead box C1 (FOXC1), a member of the forkhead box transcription factor family, is an important transcriptional regulator of crucial proteins involved in several cancers (16). 
Its expression is increased in cell proliferation, migration, angiogenesis, and cancer stem cell (CSC) maintenance (16). FOXC1 induces CSC-like properties in non-small cell lung cancer (NSCLC) by promoting $\beta$-catenin expression in vitro and in vivo, suggesting $\mathrm{FOXC1}$ as a promising molecular target for anti-CSC-based therapies in NSCLC (17). FOXC1 is overexpressed and associated with poor survival in triplenegative breast cancer (TNBC). It was reported that WNT5A and matrix metalloproteinase 7 (MMP7) were up-regulated by FOXC1 in TNBC cells (18). In addition, FOXC1 overexpression has been shown to promote CRC invasion and lung metastasis (19).

MMP7 has been identified as an important downstream effector of FOXC1-mediated invasiveness (20). MMP7 is associated with invasive tumor growth and distant metastasis in CRC $(21,22)$. Elevated expression of MMP7 has been reported in several major types of cancer, including CRC and pancreatic carcinoma $(23,24)$. MMP7 is also known to enhance angiogenesis via degradation of soluble vascular endothelial growth factor (VEGF) receptor-1 and to potentially promote metastasis of colon carcinoma cells $(25,26)$.

The role of COUP-TFII in CRC is not clearly defined. Therefore, we established a stable cell line knocking-down COUP-TFII in the CRC cell line HT-29, which exhibits high endogenous COUP-TFII expression, and examined the effects of COUP-TFII knock-down on the proliferation, colony-forming ability, migration, and invasion of HT-29 cells. In addition, microarray analysis was conducted to identify the target genes regulated by COUP-TFII. Our results suggest that COUP-TFII knock-down enhanced cell proliferation and invasion via activation of Akt pathway and increased expression of FOXC1 in HT-29 cells.

\section{Materials and Methods}

Cell cultures. The human CRC cell line HT-29 was obtained from the Korean Cell Line Bank (Seoul National University, Seoul, Republic of Korea), established from moderately differentiated human colon adenocarcinoma, and cultured in Dulbecco's modified Eagle's medium (DMEM) (Hyclone, Logan, UT, USA) supplemented with $10 \%$ fetal bovine serum (FBS) (Gibco, Carlsbad, CA, USA), $100 \mathrm{U} / \mathrm{ml}$ penicillin, and $100 \mu \mathrm{g} / \mathrm{ml}$ streptomycin (Hyclone, Pasching, Austria). Cultures were maintained in a humidified atmosphere of $5 \% \mathrm{CO}_{2}$ at $37^{\circ} \mathrm{C}$.

Chemicals and antibodies. Crystal violet and agarose were purchased from Sigma-Aldrich (St. Louis, MO, USA). Akt inhibitor IV (124015) was purchased from Calbiochem (San Diego, CA. USA). Anti-Akt (\#4685), anti-p-Akt (\#4060), anti-Cyclin D1 (\#2926), antiphosphatase and tensin homologue deleted on chromosome 10 (PTEN) (\#9556), anti-glycogen synthase kinase (GSK)-3 $\beta$ (\#9332), anti-p-GSK-3ß (\#9336), anti-N-cadherin (\#13116), and anti-Ecadherin (\#3195) antibodies were obtained from Cell Signaling Technology (Danvers, MA, USA). Anti-vimentin (ab92547), anti-cMyc (ab32072), anti-FOXC1 (ab5079), and anti-MMP7 (ab5706) antibodies were acquired from Abcam (Cambridge, UK), while antiCOUP-TFII antibody (PP-H7147-00) from Perseus Proteomics Inc. (Tokyo, Japan). The anti- $\beta$-actin (A1978), anti-rabbit IgG (A0545), and anti-mouse IgG secondary antibodies (A9044) were purchased from Sigma-Aldrich. Unless otherwise stated, all other chemicals were purchased from Sigma-Aldrich.

Generation of COUP-TFII-knock-down HT-29 cell line. HT-29 cells were transfected with $2 \mu \mathrm{g}$ of SureSilencing shRNA plasmid for human NF2F2 (KH05883P), as well as a non-targeting control (NC) shRNA (Qiagen, Hilden, Germany) using Lipofectamine 2000 (Invitrogen, Carlsbad, CA, USA) following the manufacturer's recommended instructions. After transfection, stable cell lines were established after puromycin selection $(5 \mu \mathrm{g} / \mathrm{ml})$ for 14 days.

Cell counting assay. Cells from both groups (COUP-TFII-knockdown and NC control) were seeded in 6 -well plates $\left(1.5 \times 10^{5} /\right.$ well $)$ and cultured for 24, 48 and $72 \mathrm{~h}$. After incubation, the cells were treated with trypsin/EDTA and stained with trypan blue. The live cells were counted using a hemocytometer. The experiments were repeated three times.

Cell proliferation assay. Carboxyfluorescein diacetate succinimidyl ester (CFSE) labeling assay was performed to evaluate cell proliferation as previously described $(27,28)$. In brief, cells (COUPTFII-knock-down and NC control group) were washed with PBS three times, and treated with $1 \mu \mathrm{M}$ CFSE (Molecular Probes, Invitrogen) for $15 \mathrm{~min}$. After washing, the cells $\left(1 \times 10^{5}\right.$ cells/well $)$ were incubated with a fresh medium containing $10 \%$ FBS, seeded, and cultured for 24,48 , or $72 \mathrm{~h}$ in 6-well plates. Cells were analyzed using flow cytometry (FACSCalibur; BD Biosciences). Each experiment was performed in triplicate.

Western blot analysis. Cell lysates were obtained from COUPTFII-knock-down and control cells and western blot analyses were performed as described previously (29). The protein concentration in each lysate was determined using the Bio-Rad Protein Assay Reagent (Bio-Rad Lab., Richmond, CA, USA), according to the manufacturer's procedure. The lysate samples (30 $\mu \mathrm{g}$ protein each) were subjected to SDS-PAGE. After electrophoresis, the separated proteins were transferred to PVDF membranes (Merck Millipore, Darmstadt, Germany). Blots were blocked with 5\% skim milk in PBS at room temperature (RT) for $1 \mathrm{~h}$. The blots were probed with the appropriate primary antibody overnight. After washing, blots were probed with a secondary antibody for $2 \mathrm{~h}$. After another wash, the signals were detected with ECL detection reagents (Amersham, Buckinghamshire, UK) according to the manufacturer's protocol. The blots were also probed with a monoclonal anti- $\beta$-actin antibody, which served as an internal control. Bands were quantified using Image Studio Lite Ver 3.1 (LI-COR, Inc., Lincoln, NE, USA).

Immunofluorescence staining. HT-29 cells from both groups (COUP-TFII-knock-down and NC control) were cultured on a Lab$\mathrm{Tek}^{\circledR}{ }^{\circledR}$ ChamberSlide ${ }^{\mathrm{TM}}$ (Nalgene Nunc, Inc., Rochester, NY, USA). Cells were fixed with $3 \%$ formaldehyde, permeabilized using $0.3 \%$ Triton X-100, and blocked for $30 \mathrm{~min}$ with $5 \%$ bovine serum albumin (BSA) at RT. After wash, a series of antibodies were used as indicated, followed by staining with FITC-conjugated anti-mouse IgG, Alexa-488-conjugated anti-rabbit IgG or Cy3-conjugated anti- 
A

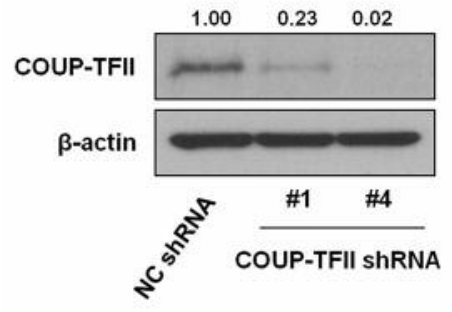

B

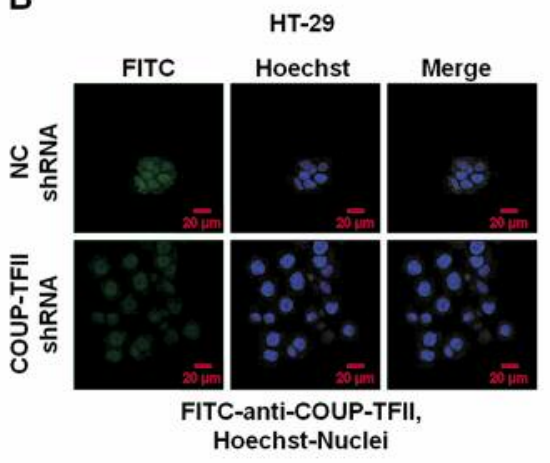

C

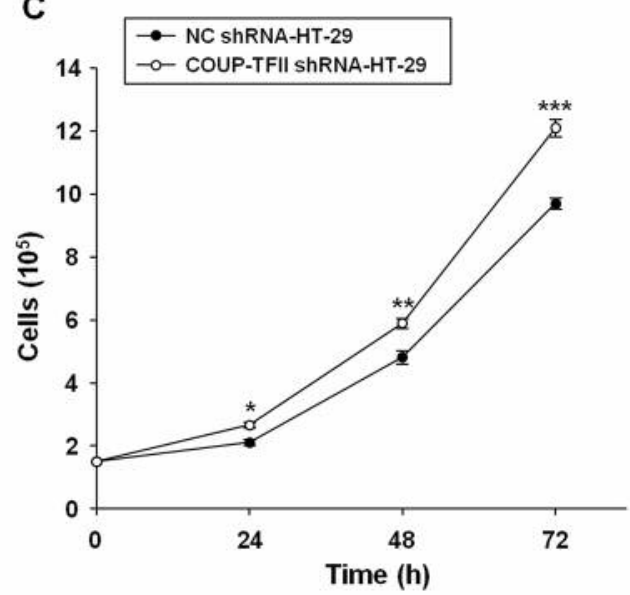

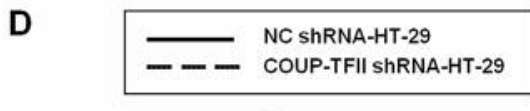
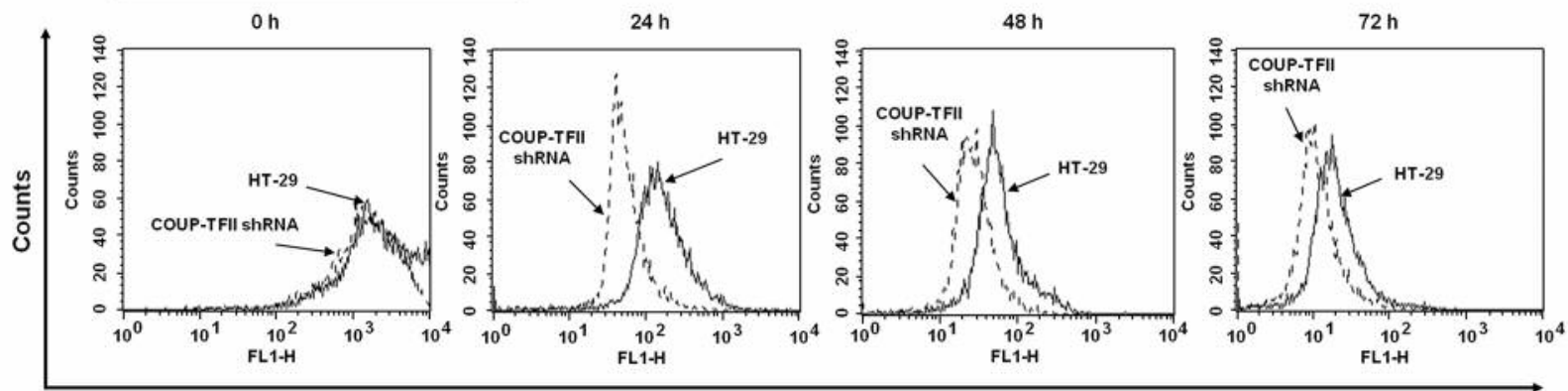

CFSE

$\mathbf{E}$
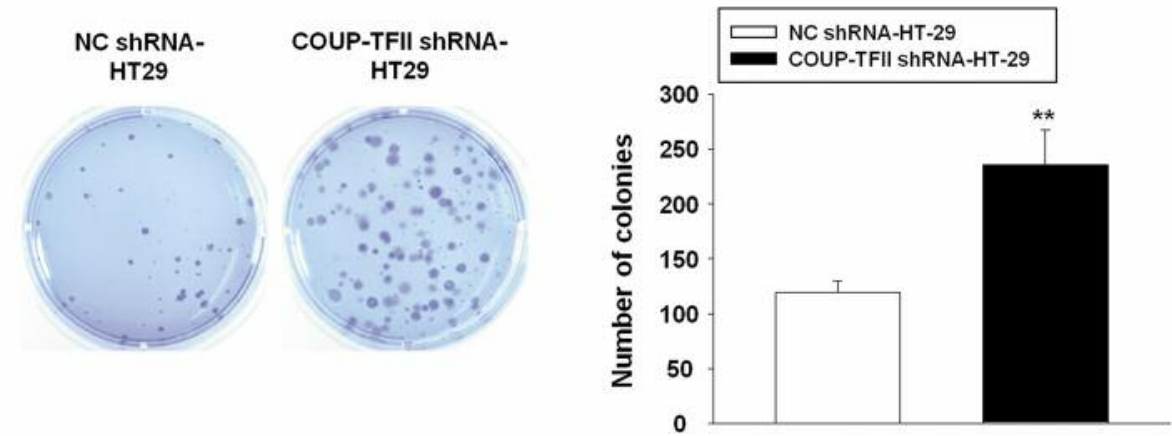

Figure 1. Knock-down of chicken ovalbumin upstream promoter-transcription factor II (COUP-TFII) enhances cell proliferation and colony-forming ability of HT-29 cells. (A and B) Establishment of COUP-TFII knock-down stable cell lines in HT-29 cells: The expression of COUP-TFII was evaluated by western blot (A); $\beta$-actin was used as a loading control and densitometry results (values above each lane) were expressed relative to the non-targeting control (NC) shRNA group. Representative data of three independent experiments are shown. (B) Immunofluorescence staining was also used to confirm knock-down of COUP-TFII (FITC) in the COUP-TFII shRNA-HT-29 cells. Cell nuclei were stained with Hoechst dye. (C) Cell proliferation was evaluated with a cell counting assay at the indicated time points $(24,48$, and $72 \mathrm{~h})$. (D) Cells were stained with carboxyfluorescein diacetate succinimidyl ester (CFSE) before plating, then were cultured for the indicated times, and analyzed by flow cytometry as described in the Materials and methods. (E) Colony formation assay was performed in NC shRNA- and COUP-TFII shRNA-HT-29 cells. The numbers of colonies were counted and shown graphically. Each value is expressed as mean \pm standard deviation $(S D)(n=3) .{ }^{*} p<0.05$, ** $p<0.01, * * * p<0.001$, versus NC shRNA-HT-29 cells.

rabbit IgG (Santa Cruz Biotechnology, Santa Cruz, CA, USA). Cell nuclei were stained with Hoechst dye. The samples were mounted using glycerol, and analyzed with a confocal microscope (Carl Zeiss LSM800; Carl Zeiss, Jena, Germany) using a 40× C-Apochromat objective. Negative control staining was carried out using only secondary antibodies.
Wound healing assay. Cells were seeded in 6-well plates and incubated for $48 \mathrm{~h}$ at $37^{\circ} \mathrm{C}$ until $>90 \%$ confluence. A straight wound was created using a $200-\mu 1$ pipette tip. After washing with serumfree medium twice, the cells were cultured to migrate into the wound area. Images of the migrated cells were captured with an inverted microscope (Nikon Eclipse TS100; Nikon, Tokyo, Japan). 
Transwell invasion assay. Cell invasion was determined using Transwell chambers (Corning Inc., Lowell, MA, USA). Cells $\left(1 \times 10^{5}\right)$ were suspended in $200 \mu \mathrm{l}$ of serum free medium and inoculated into each upper chamber of the 24 well plates, which were precoated with $50 \mu \mathrm{l}$ of Matrigel ( $1 \mu \mathrm{g} / \mu \mathrm{l}$; BD Biosciences, San Jose, CA, USA). The lower chamber was suspended in $600 \mu \mathrm{l}$ DMEM with $10 \%$ FBS and incubated for $48 \mathrm{~h}$ at $37^{\circ} \mathrm{C}$ with $5 \% \mathrm{CO}_{2}$. The cells on the upper surface were removed with a cotton swab and the cells that migrated to the underside of the membrane were fixed with $4 \%$ formaldehyde in PBS for 30 min at RT, stained with $0.1 \%$ crystal violet (Sigma Aldrich) for $20 \mathrm{~min}$ and washed with PBS three times. The cells in five random fields at $\times 200$ magnification were counted using an inverted microscope (Nikon Eclipse TS100). It was expressed as the average number of cells/field of view.

Colony formation assay. The adhesion-independent proliferation of cells was evaluated by colony formation assay. Briefly, a bottom layer of medium containing $0.5 \%$ agar was placed in 6 -well plates (SPL, Pocheon-si, Gyeonggi-do, Republic of Korea). Cells suspended in $0.35 \%$ agar medium were added in each well $\left(1 \times 10^{4}\right.$ cells/well) and were incubated at $37^{\circ} \mathrm{C}$. The culture medium was replaced with fresh every 2 days. After 2 weeks, the cells were washed with PBS and stained with $0.1 \%$ crystal violet for $20 \mathrm{~min}$ at RT. The total fields were counted under an inverted microscope at $\times 100$ magnification. All experiments were performed in triplicate.

Microarray analysis. Total RNA from NC shRNA-HT-29 and COUPTFII shRNA-HT-29 cells was extracted using TRIzol reagent (Invitrogen, Carlsbad, CA, USA). The Affymetrix Whole Transcript Expression array procedure was performed according to the manufacturer's protocol (GeneChip Whole Transcript PLUS Reagent Kit). The cDNA was synthesized using the GeneChip Whole Transcript (WT) amplification kit as described by the manufacturer. The sense cDNA was fragmented and labeled with biotin linked to terminal deoxynucleotidyl transferase (TTT) using the GeneChip WT Terminal labeling kit. The labeled DNA target (approximately $5.5 \mu \mathrm{g}$ ) was hybridized on an Affymetrix Gene Chip Human 2.0 ST Array at $45^{\circ} \mathrm{C}$ for $16 \mathrm{~h}$. Hybridized Affymetrix Gene Chip Human 2.0 ST arrays were washed and stained with Gene Chip Fluidics Station 450 and scanned with a GCS3000 scanner (Affymetrix). Signal values were verified by Affymetrix ${ }^{\circledR}$ GeneChip ${ }^{\mathrm{TM}}$ Command Console software.

Dominant negative (DN)-Akt expression vector transfection and Akt inhibitor IV treatment. The COUP-TFII shRNA-HT-29 cells were transfected with $2 \mu \mathrm{g}$ of DN-Akt expression vector (DN-Akt; \#21152 ) or the empty vector (pUSEamp; \#21-147, Upstate Technology) using lipofectamine 2000, according to the manufacturer's instructions. After transfection, cells were cultured in 10\% FBSsupplemented DMEM for $48 \mathrm{~h}$. In addition, the COUP-TFII shRNA-HT-29 cells were treated with Akt inhibitor IV and cultured in $10 \%$ FBS-supplemented DMEM for $48 \mathrm{~h}$. These cells were then used to determine cell proliferation, and conduct transwell invasion assay, immunofluorescence staining and western blot analysis.

Statistical analysis. Statistical analyses were performed using the SPSS 23.0 statistical package for Windows (SPSS, Chicago, IL, USA). Data are expressed as the mean \pm standard deviation (SD) from three independent experiments. The unpaired Student's $t$-test was used to determine statistical significance. Statistical significance was defined as $p<0.05$.

\section{Results}

Knock-down of COUP-TFII promoted cell proliferation and colony formation. To examine the effects of COUP-TFII knock-down on the HT-29 cell line, COUP-TFII was stably knocked-down using the COUP-TFII shRNA vector. NC shRNA was used as the control. Western blot analysis (Figure 1A) and immunofluorescence staining (Figure 1B) confirmed effective down-regulation of COUP-TFII in COUP-TFII shRNA-HT-29 (\#1, 4) cells.

COUP-TFII knock-down significantly enhanced the proliferation of HT-29 cells, as shown by cell counting (1.25fold compared to NC shRNA-HT-29 cells, $p<0.0001$ at $72 \mathrm{~h}$; Figure 1C) as well as by the CFSE proliferation assay (Figure 1D). Moreover, COUP-TFII knock-down promoted colony formation in HT-29 cells (1.98-fold, $p<0.01$, compared to the control cells; Figure 1E). Our data indicated that COUP-TFII knock-down promoted both cell proliferation and colonyforming ability of HT-29 cells.

Knock-down of COUP-TFII enhanced the migration and invasion of HT-29 cells. To investigate the effect of COUPTFII knock-down on migration and invasion, NC shRNAHT-29 and COUP-TFII shRNA-HT-29 cells were evaluated via wound-healing assay and transwell invasion assay. In the wound-healing assay, scratch-wound closure was more rapid in COUP-TFII shRNA-HT-29 cells $(2.49$-fold at $24 \mathrm{~h}$,

Figure 2. Knock-down of chicken ovalbumin upstream promotertranscription factor II (COUP-TFII) promoted cell migration and invasion. (A) Upper panel: Representative findings of non-targeting control (NC) ShRNA group and COUP-TFII shRNA-HT-29 cells in the wound healing assay are presented (magnification $\times 100$ ). Lower panel: The extent of cell migration is indicated as the percentage of scratch wound closure compared to the scratch area at time point $0 \mathrm{~h}$. Data are presented as the mean $\pm S D$ of at least three experiments. ${ }^{*} p<0.05$, $* * p<0.01$, versus NC shRNA-HT-29 cells. (B) Upper panel: Two representative images of the transwell invasion assay are presented (magnification $\times 200$ ); cell invasion was markedly enhanced in the COUP-TFII ShRNA-HT-29 compared to the control NC shRNA-HT-29 group. Lower panel: To quantify invasion assay results, the invaded cells were counted in five randomly chosen visual fields, and data are presented in the graph as the mean $\pm S D$ of three experiments. ***p<0.001, vs. the NC shRNA-HT-29 cells. (C) Protein expression of COUP-TFII and epithelial-mesenchymal transition (EMT) biomarkers such as E-cadherin, $N$-cadherin and vimentin was determined by western blot analysis. Representative western blots of three experiments are shown. Densitometry results (values above each lane) were expressed relative to the control group (NC shRNA-HT-29 cells), after normalization to loading control $\beta$-actin. Representative data of three independent experiments are shown. (D) Quantified western blot results are also presented in the chart; data are presented means $\pm S D$ of three experiments. ${ }^{*} p<0.01,{ }^{* *} p<0.001$, vs. the NC shRNA-HT-29 cells. 


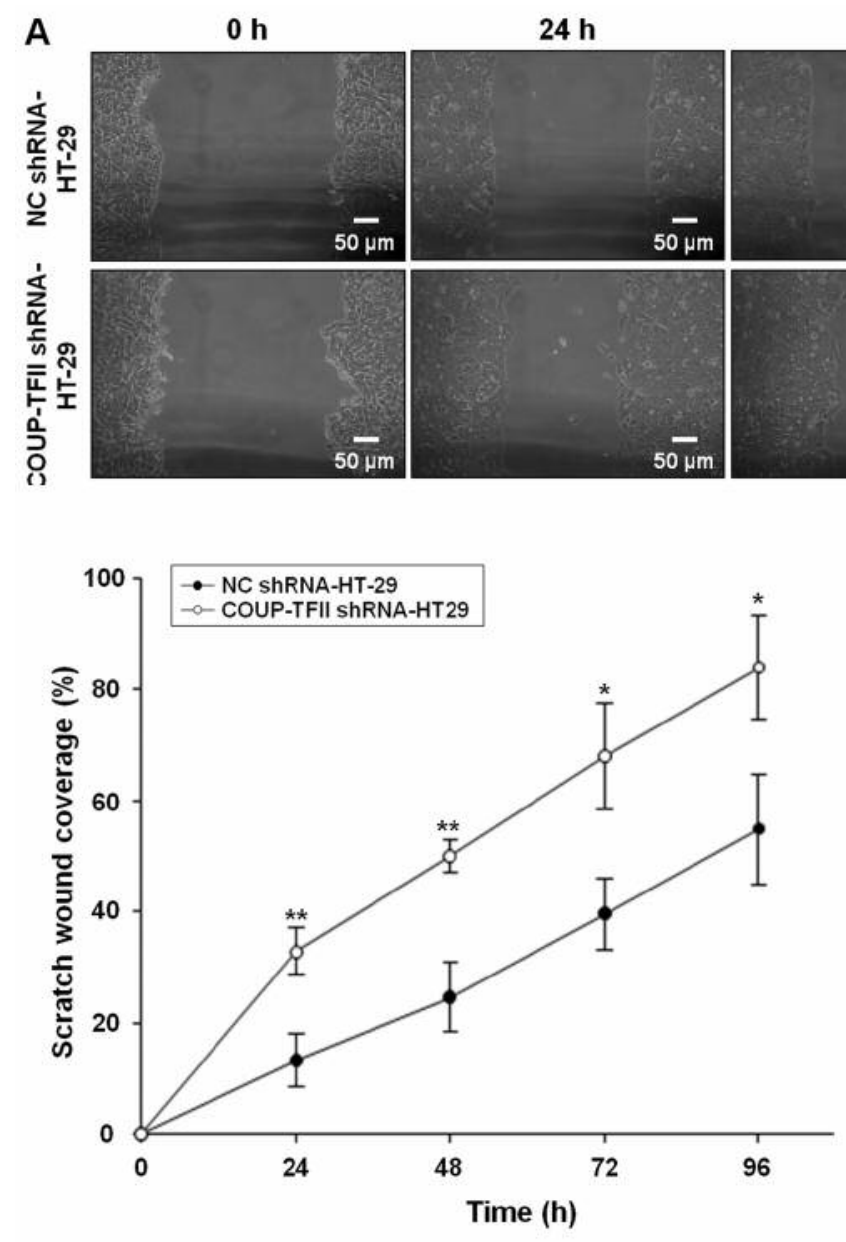

$48 \mathrm{~h}$

$72 \mathrm{~h}$

$96 \mathrm{~h}$

C

HT-29
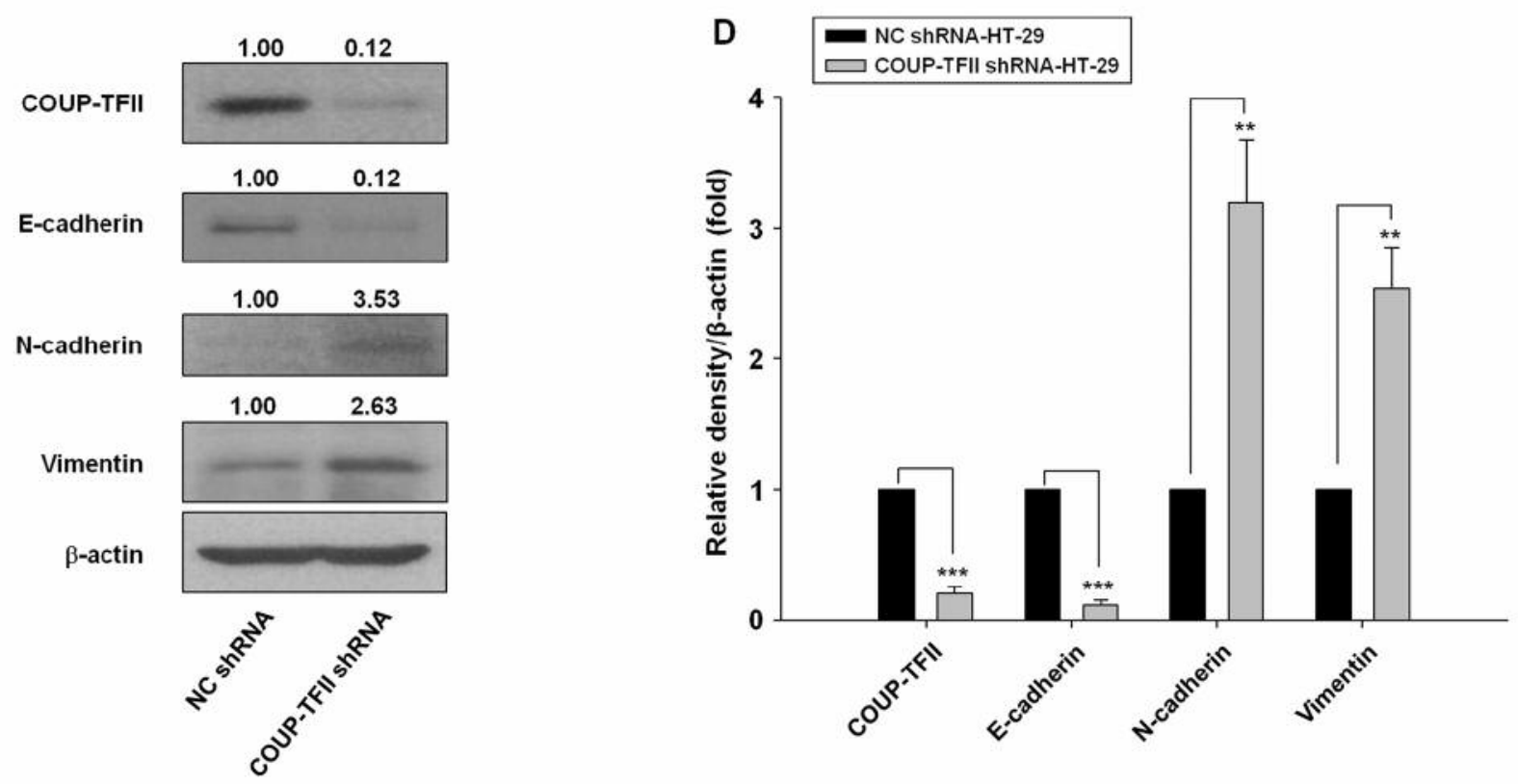
A

Up- and down-regulated probe count (fold change between the COUP-TFII ShRNA-HT29 and NC shRNA-HT-29 group $\geq 2$ )

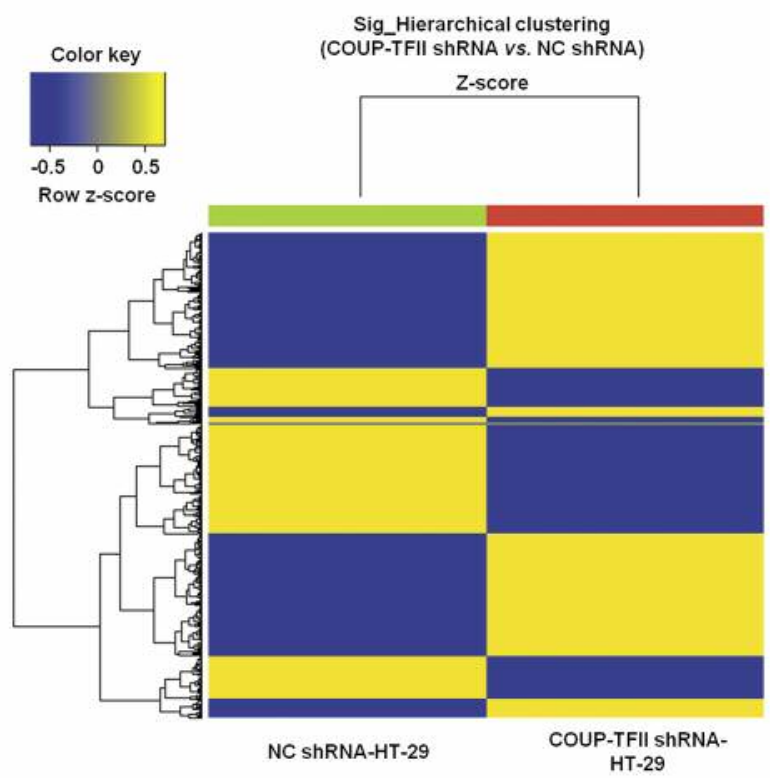

C

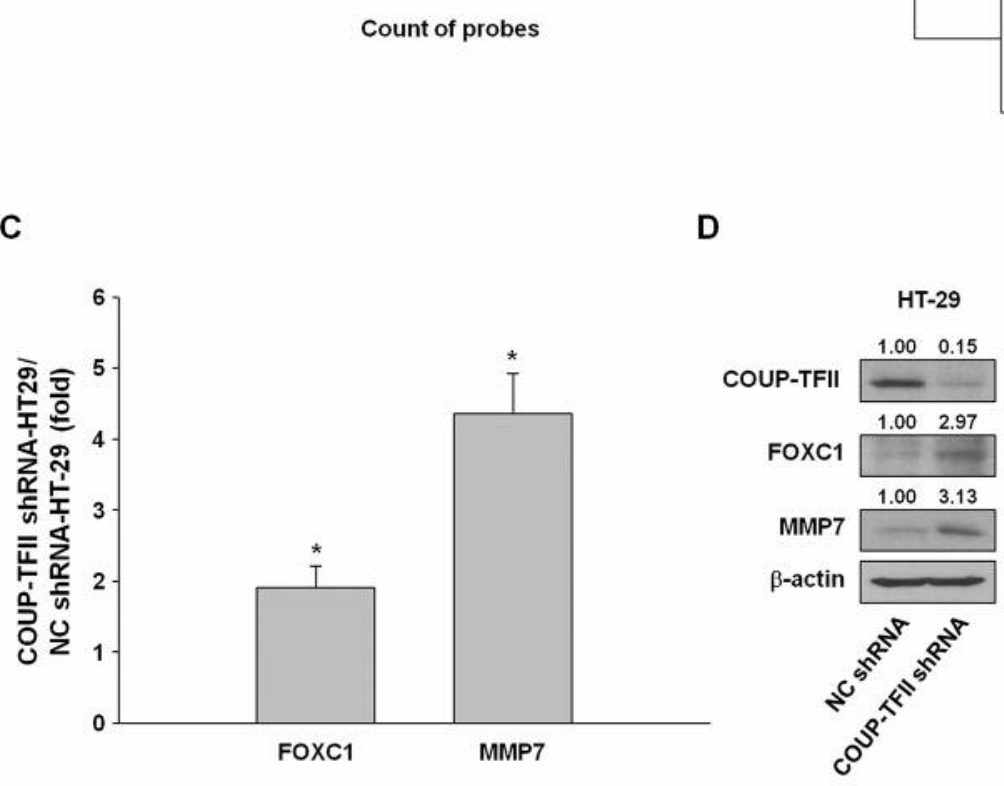

Up

Down
0
500

Count of probes

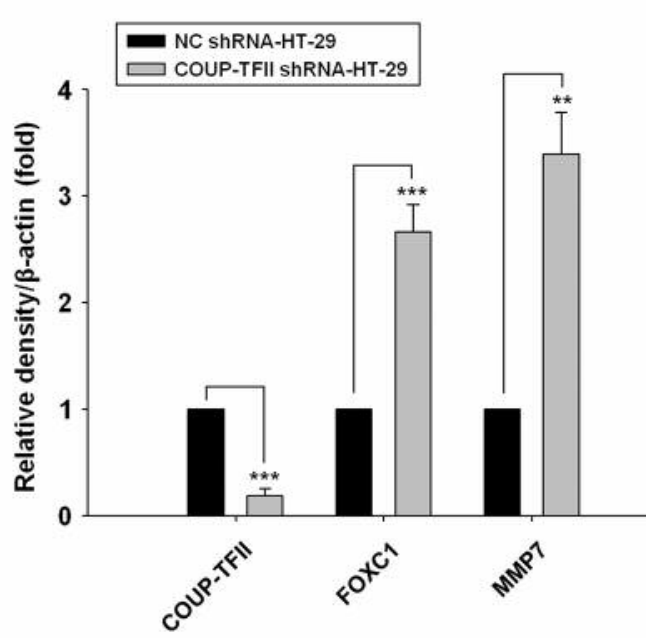

Figure 3. Comparison of microarray findings with western blots of chicken ovalbumin upstream promoter-transcription factor II (COUP-TFII) shRNA- and non-targeting control (NC) shRNA-HT-29 cells. (A) A total of 553 differentially expressed genes were identified in COUP-TFII shRNAHT-29 compared to NC shRNA-HT-29 cells (fold change $>2$ and $p<0.05$ ) including 225 up-regulated and 328 down-regulated genes. (B) The heatmap of differentially expressed genes generated from microarray analysis is shown. The color scale at the top left of the heatmap represents normalized expression data (yellow indicates up-regulation and blue denotes down-regulation). (C) Expression levels of two up-regulated genes [forkhead box C1 (FOXC1) and matrix metalloproteinase 7 (MMP7)] were compared between COUP-TFII shRNA-HT29 and NC shRNA-HT-29 cells. (D) Expression levels of FOXC1 and MMP7 were also examined by western blot analysis. Densitometry results (values above each lane) were expressed relative to the control group (NC shRNA-HT-29 cells), after normalization to loading control $\beta$-actin. Representative data of three independent experiments are shown. Quantified western blot results are also presented in the chart; data are presented means $\pm S D$ of three experiments. ${ }^{*} p<0.05$, $* * p<0.01, * * * p<0.001, v s$. the NC shRNA-HT-29 cells.

$p<0.01 ; 2.05$-fold at $48 \mathrm{~h}, p<0.01 ; 1.72$-fold at $72 \mathrm{~h}, p<0.05$; and 1.53 -fold at $96 \mathrm{~h}, p<0.05)$, compared to NC shRNA-HT29 cells (Figure $2 \mathrm{~A}$ ). In the transwell invasion assay, the number of invading cells was significantly increased in the COUP-TFII shRNA-HT-29 compared to the NC shRNA-HT29 group (10.04-fold, $p<0.001$ ) (Figure $2 \mathrm{~B}$ ). In order to explain this finding, the expression levels of epithelialmesenchymal transition (EMT)-related markers were evaluated by western blot analysis in NC shRNA-HT-29 and COUP-TFII shRNA-HT-29 cells. COUP-TFII knock-down significantly increased the expression levels of $\mathrm{N}$-cadherin (3.19 \pm 0.48 -fold, $p<0.01)$ and vimentin $(2.54 \pm 0.32$-fold, 
A

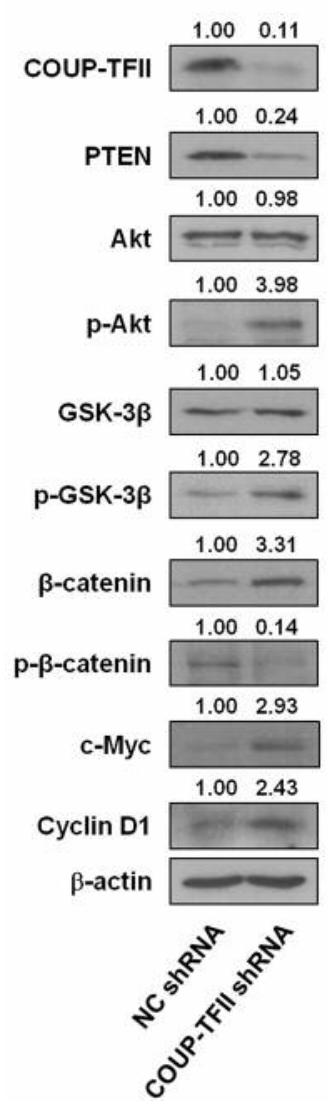

B

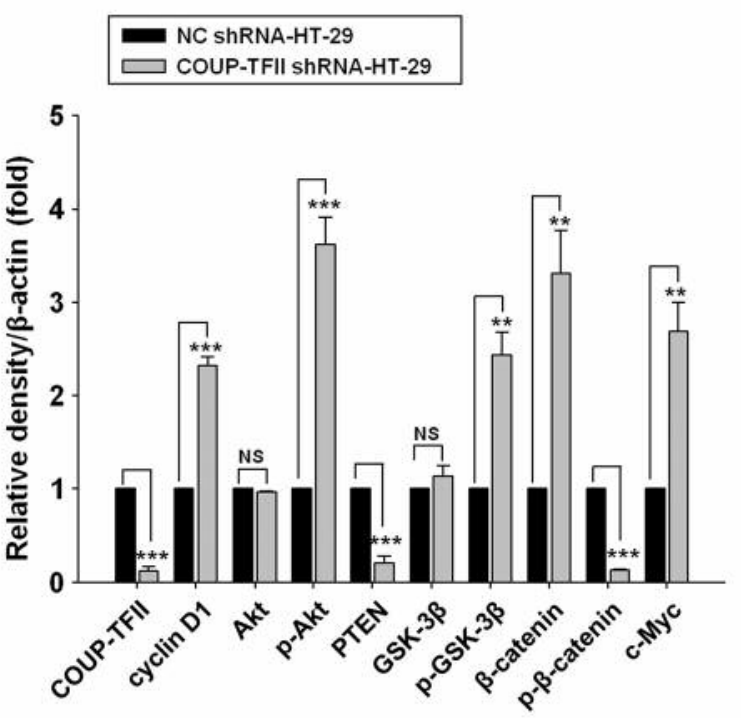

C

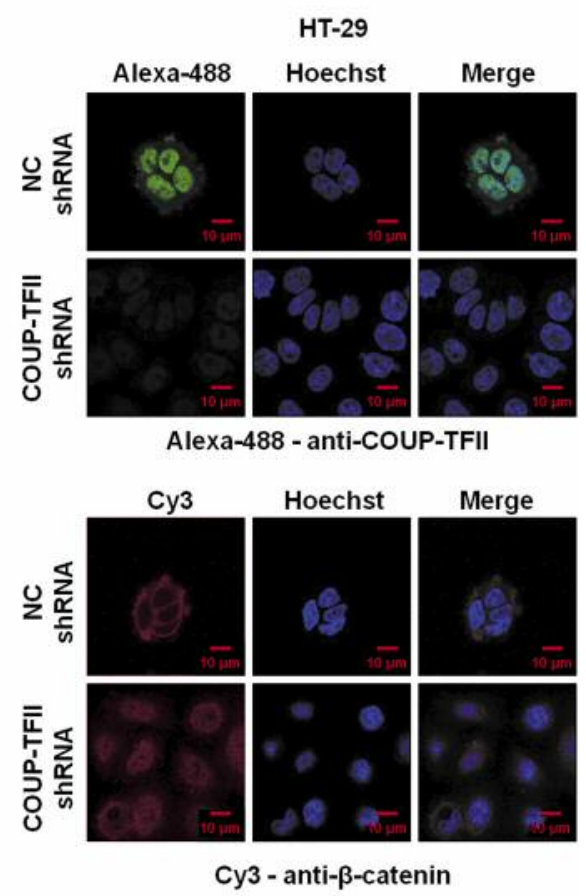

Figure 4. Chicken ovalbumin upstream promoter-transcription factor II (COUP-TFII) knock-down enhanced the protein levels of p-Akt, p-glycogen

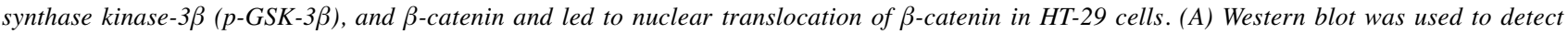
the key signaling molecules. Densitometry results (values above each lane) were expressed relative to the non-targeting control (NC) shRNA group after normalization to loading control $\beta$-actin. Representative data of three independent experiments are presented. (B) Quantified western blot results are also presented in the chart; data are presented means $\pm S D$ of three experiments. $* * p<0.01, * * * p<0.001$ indicates significant difference compared to the control (NC shRNA-HT-29 cells). NS denotes no significance. (C) The expression of COUP-TFII (Alexa-488) and $\beta$-catenin (Cy3) in NC shRNA- and COUP-TFII shRNA-HT-29 cells was detected by immunofluorescence staining. Cell nuclei were stained with Hoechst dye. The results are representative of three separate experiments.

$p<0.01)$, and decreased the expression of E-cadherin $(0.12 \pm 0.04$-fold, $p<0.001)$ compared to control cells (Figure 2D). These results suggested that COUP-TFII knock-down enhanced migration and invasion via induction of EMT.

Analysis of differentially expressed mRNA between COUPTFII shRNA- and NC shRNA-HT-29 cells. As described above, silencing of COUP-TFII resulted in increased cell proliferation, migration, and invasion of HT-29 cells. To identify the molecules implicated in these processes, microarray analyses were performed using NC shRNA- and COUP-TFII shRNA-HT-29 cells. Microarray results showed that 553 (filtering criteria; fc $>2.0$ ) mRNAs were differentially expressed between COUP-TFII shRNA-HT-29 and NC shRNA-HT-29 groups. Among the differentially expressed genes, 225 ( $\mathrm{fc}>2.0$ ) were up-regulated and 328 ( $\mathrm{fc}>2.0$ ) were down-regulated (Figure 3A). The heatmaps for sample and probe identification of similar expression levels (normalized values) were grouped into hierarchical clusters (Euclidean method, full linkage). The heatmap of the two groups showed a distinct mRNA expression profile (Figure 3B). As shown in Figure 3C, FOXC1 and MMP7, which are important molecules related to EMT and invasion $(17,20)$, were significantly increased in COUP-TFII shRNA-HT-29 cells (1.91 \pm 0.20 -fold, $p<0.05$ and $4.36 \pm 0.56$-fold, $p<0.05$, respectively) compared to NC shRNA-HT-29 cells. The expression of the two differentially expressed genes was validated by western blot. The results showed that FOXC1 and MMP7 expressions were significantly increased in COUP-TFII shRNA-HT-29 cells compared to NC shRNA- 
HT29 cells (FOXC1: $2.66 \pm 0.26$-fold, $p<0.001$, MMP7: $3.39 \pm 0.40$-fold, $p<0.01$; Figure $3 \mathrm{D}$ ). These results were consistent with those of the microarray analysis (Figure 3C). These data suggest that FOXC1 and MMP7 may contribute to enhanced migration and invasion in COUP-TFII shRNAHT-29 cells.

COUP-TFII knock-down activated Akt/GSK-3 $\beta / \beta$-catenin pathway in HT-29 cells. To elucidate the possible mechanism by which COUP-TFII knock-down enhances FOXC1 and MMP-7 expression, we evaluated the protein expression of Akt/GSK-3 $\beta / \beta$-catenin signaling pathway in COUP-TFII shRNA- and NC shRNA-HT-29 cells. The results revealed that COUP-TFII knock-down significantly increased the protein levels of p-Akt, p-GSK-3 $\beta$, and $\beta$-catenin $(3.63 \pm 0.29$-fold, $p<0.001 ; 2.44 \pm 0.25$-fold, $p<0.01$; and $3.31 \pm 0.46$-fold, $p<0.01$, respectively), while the PTEN and $\mathrm{p}$ - $\beta$-catenin protein levels were decreased $(0.21 \pm 0.07$-fold, $p<0.001$ and $0.13 \pm 0.01$-fold, $p<0.001$, respectively) compared to NC shRNA-HT-29 cells (Figure 4A and B). It has been previously reported that PTEN inhibits the Akt pathway by removing the 3-phosphate from the phosphatidylinositol 3-kinase (PI3K) product phosphatidylinositol-3,4,5-triphosphate (PIP3) to produce phosphatidylinositiol-4,5-bisphosphate (PIP2) (30). Thus, the increased p-Akt level in COUP-TFII shRNA-HT-29 cells may be attributed to the decreased PTEN expression. In addition, Akt regulates EMT and invasion $(31,32)$. GSK-3 $\beta$ is one of the downstream targets of Akt, which is known that when directly phosphorylated at Ser9 and inactivated by p-Akt, and the inactivation of GSK-3 $\beta$ leads to stabilization and nuclear translocation of $\beta$-catenin $(33,34)$. The nuclear translocation of $\beta$-catenin induces EMT and metastasis (35). Similar to the induction of EMT and increased invasion in COUP-TFII shRNA-HT-29 cells (Figure 2), we analyzed the expression and localization of $\beta$-catenin in COUP-TFII shRNA- and NC shRNA-HT-29 cells using immunofluorescence staining. As shown in Figure 4C, $\beta$-catenin expression was increased and translocated into the nucleus in COUP-TFII shRNA-HT-29 cells, while $\beta$-catenin was localized to the membrane of control cells. These results suggested that COUP-TFII knock-down activated Akt/GSK-3 $\beta / \beta$-catenin pathway in HT-29 cells. To confirm the activation of $\beta$-catenin by COUP-TFII knockdown, the expression levels of c-Myc and cyclin D1, which are downstream targets of $\beta$-catenin (36), were analyzed. The results showed that c-Myc $(2.69 \pm 0.31$-fold, $p<0.01)$ and cyclin D1 levels $(2.33 \pm 0.09$-fold, $p<0.001)$ were increased in COUPTFII shRNA-HT-29 cells, compared to control cells (Figure 4B). Since it has been previously reported that FOXC1 expression is regulated by $\beta$-catenin (37), we suggest that the increased expression of FOXC1 induced by COUP-TFII knock-down may be attributed to the activation of $\beta$-catenin. Further studies using $\beta$-catenin shRNA knock-down are needed to investigate whether $\beta$-catenin regulates $\mathrm{FOXC1}$ expression.
Inhibition of Akt by Akt inhibitor IV and DN-Akt expression vector transfection reversed the enhanced proliferation and invasion by COUP-TFII knock-down in HT-29 cells. COUPTFII knock-down activated Akt/GSK-3 $\beta / \beta$-catenin axis in HT-29 cells. To investigate whether the increased Akt activity was required for enhanced cell proliferation and invasion by COUP-TFII knock-down, COUP-TFII shRNA-HT-29 cells were treated with Akt inhibitor IV, and the proliferation and invasion were determined. The results demonstrated that treatment with Akt inhibitor IV significantly inhibited COUPTFII knock-down-induced cell proliferation $(0.8$-fold at $24 \mathrm{~h}$, $p<0.05 ; 0.36$-fold at $48 \mathrm{~h}, p<0.001 ; 0.22$-fold at $72 \mathrm{~h}$, $p<0.001$; Figure 5B) and invasion (50.4 $\pm 5.5 v s .115 .0 \pm 4.7$ cells, $p<0.001$; Figure 5D) in COUP-TFII shRNA-HT-29 cells. Western blot analyses showed that the p-Akt level was decreased $(0.23 \pm 0.17, p<0.01)$ and the protein levels of downstream molecules [p-GSK-3 $\beta(0.99 \pm 0.04, p<0.05), \beta$ catenin $(1.24 \pm 0.04, p<0.001)$, c-Myc $(1.23 \pm 0.28, p<0.05)$, cyclin D1 $(0.89 \pm 0.13, p<0.05)$, vimentin $(1.34 \pm 0.11$, $p<0.05)$, and $\mathrm{N}$-cadherin $(2.07 \pm 0.12, p<0.01)]$ were decreased by Akt inhibitor IV (Figure 5A). In addition, the expressions of FOXC1 and MMP-7, which mediate EMT and invasion, were decreased by Akt inhibitor IV $(1.50 \pm 0.68$, $p<0.05$ and $0.49 \pm 0.01, p<0.01$, respectively; Figure 5A). Moreover, immunofluorescence staining showed that nuclear translocation of $\beta$-catenin induced by COUP-TFII knockdown was inhibited by Akt inhibitor IV. These results suggested that Akt acts upstream of GSK- $3 \beta, \beta$-catenin,

Figure 5. Akt inhibitor IV reversed the enhanced cell proliferation and invasion induced by chicken ovalbumin upstream promoter-transcription factor II (COUP-TFII) knock-down. (A) Left panel: Akt inhibitor IV was added to COUP-TFII-shRNA-HT-29 cells. Protein lysates were analyzed by western blot analysis. $\beta$-actin was used as a loading control. The blot is representative of three separate experiments. Densitometry results (values above each lane) were expressed relative to the nontargeting control (NC) shRNA, after normalization to loading control $\beta$-actin. Right panel: Quantified western blot results are also presented in the chart; data are presented means $\pm S D$ of three experiments. ${ }^{*} p<0.05, * * * p<0.001 \mathrm{vs.}$. NC shRNA-HT-29 cells; ${ }^{\#} p<0.05,{ }^{\# \#} p<0.01$ vs. COUP-TFII shRNA-HT-29 cells. NS denotes no significance. (B) After the addition of Akt inhibitor IV, the effects of COUP-TFII knockdown on cell proliferation were significantly reversed. $* p<0.05$, ***p $<0.001$ vs. NC shRNA-HT-29 cells; \#\#\#p<0.001 vs. COUP-TFII shRNA-HT-29 cells. (C) The ability of the Akt inhibitor IV to reverse the effects of COUP-TFII knock-down on cell proliferation was also confirmed by CFSE staining. (D) Akt inhibitor IV reversed the enhanced cell invasion induced by COUP-TFII knock-down. $* * * p<0.001$ vs. NC sRNA-HT-29 cells; \#\#\#p<0.001 vs. COUP-TFII shRNA-HT-29 cells. (E) Akt inhibitor IV inhibited nuclear translocation of $\beta$-catenin (Cy3) induced by COUP-TFII knock-down in COUP-TFII shRNA-HT-29 cells. Cell nuclei were stained by Hoechst dye. The results are representative of three separate experiments. 
A

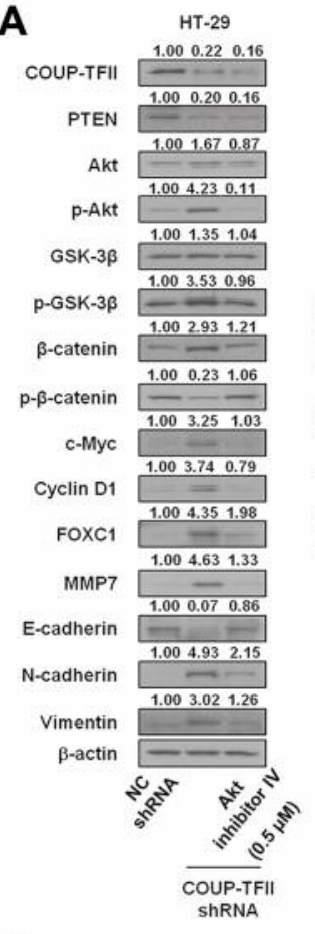

B

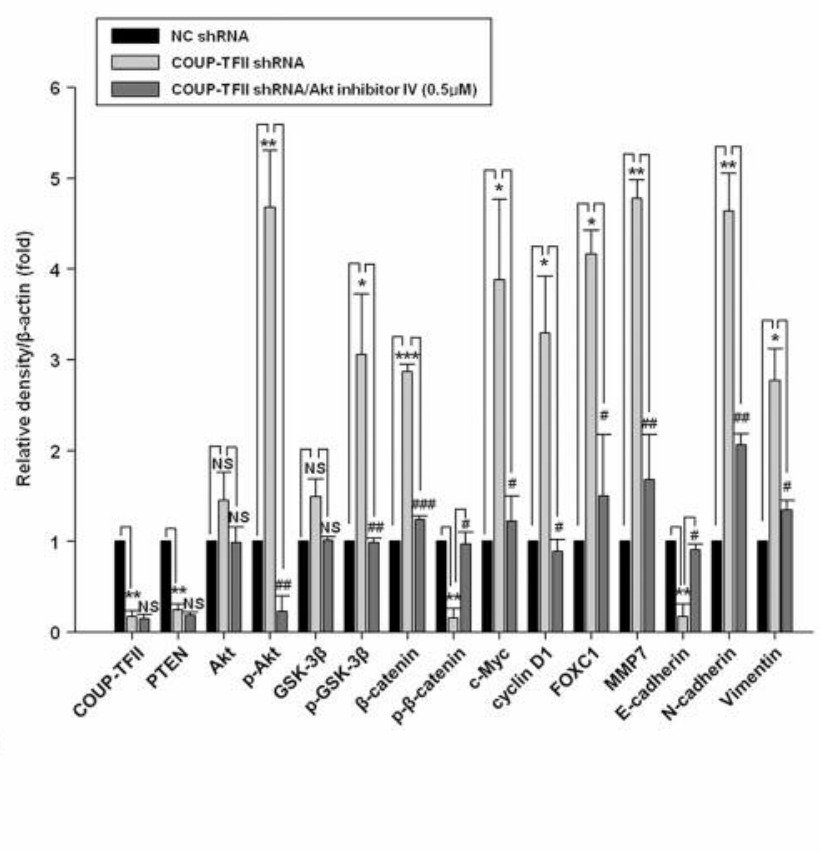

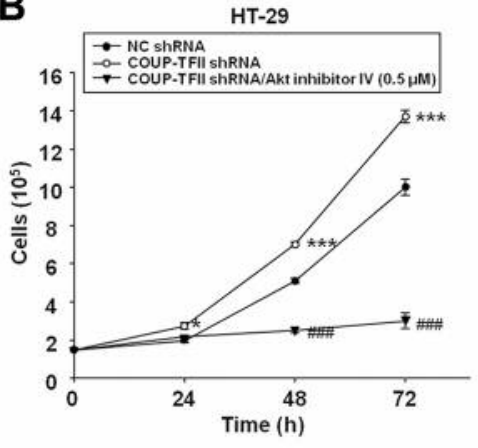

C
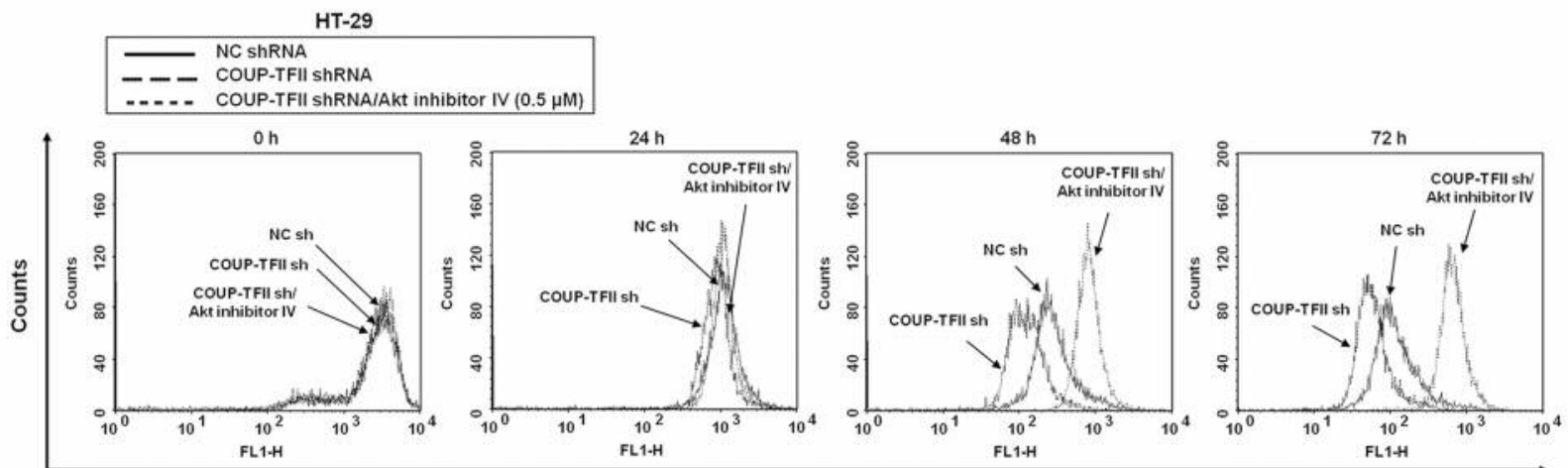

CFSE
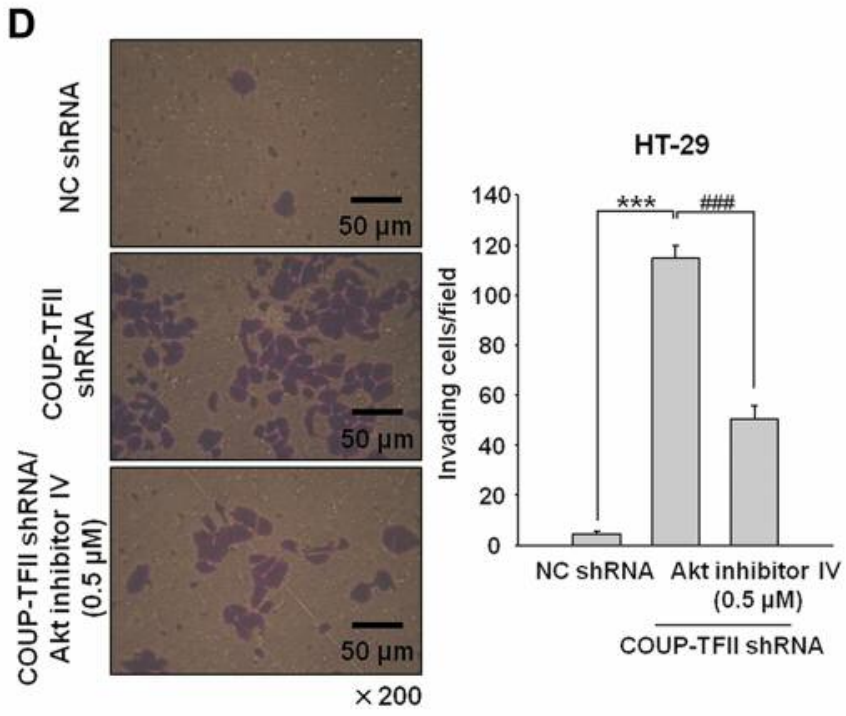

E

$2 \sum_{\frac{\alpha}{n}}^{\frac{\pi}{n}}$

Су3

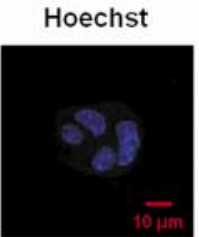

Merge
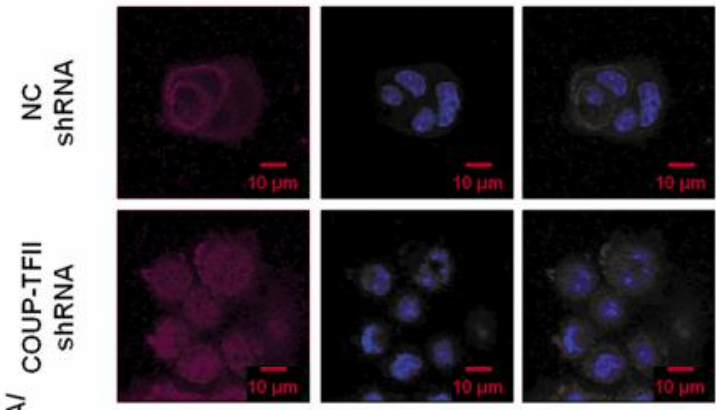

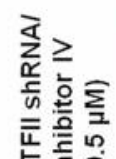

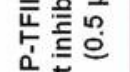

잉
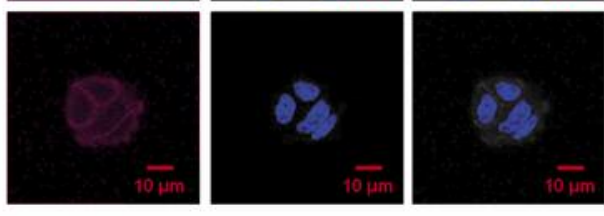

Cy3 - anti- $\beta$-catenin 


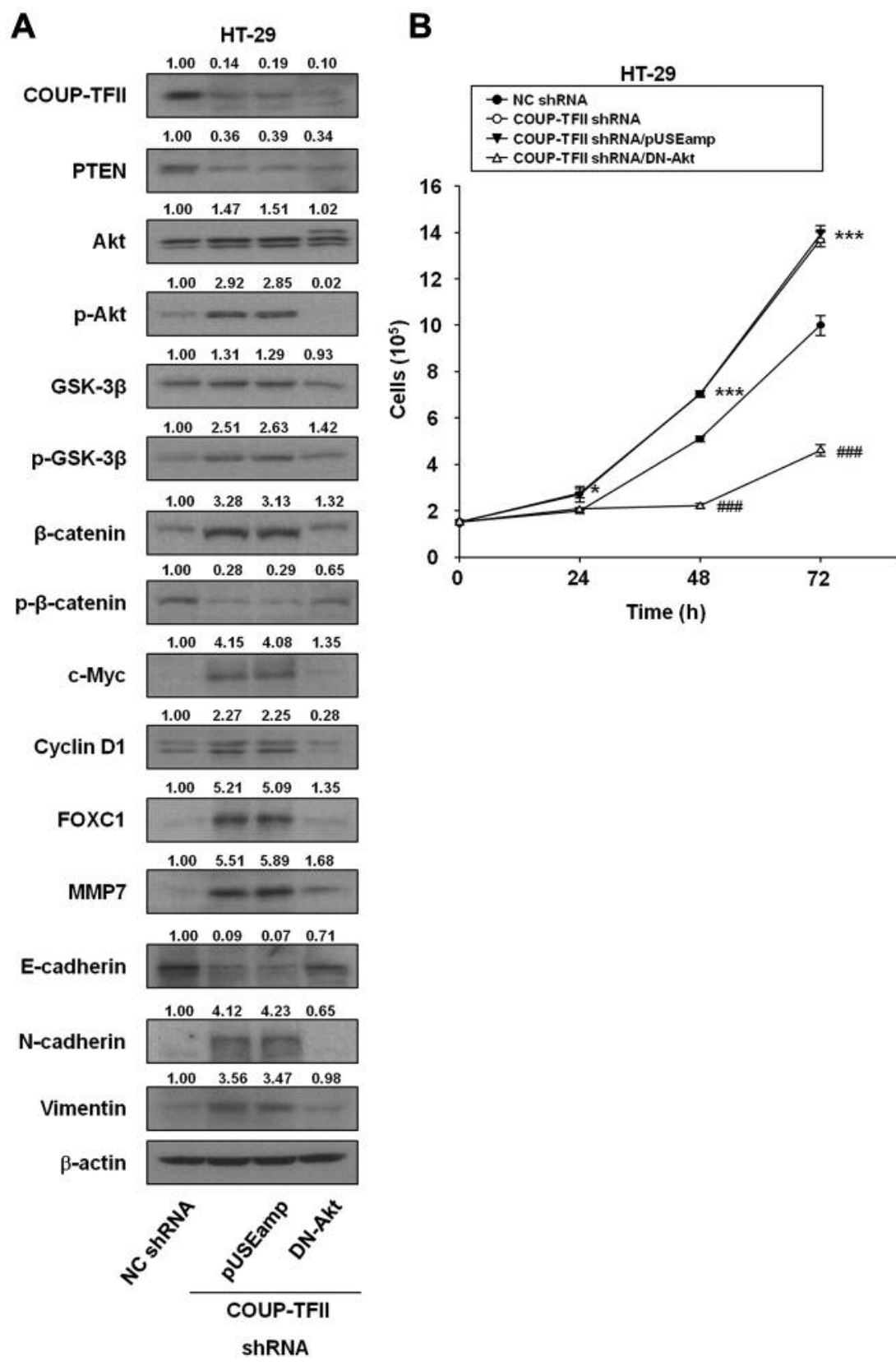

Figure 6. Continued

FOXC1, and MMP-7. To confirm these observations, DN-Akt expression vector was transfected into COUP-TFII shRNAHT-29 cells. Cell proliferation and invasion assays, western blot, and immunofluorescence staining analyses were performed. The results were similar to those of Akt inhibitor IV pretreatment (Figure 6). Taken together, these results indicated that COUP-TFII knock-down enhanced cell proliferation and invasion via activation of the Akt/GSK$3 \beta / \beta$-catenin pathway in COUP-TFII shRNA-HT-29 cells.

\section{Discussion}

Despite intensive studies investigating the role of COUPTFII in cancer, its role and mechanisms have not been wellestablished (9-13). Most of studies suggest that COUP-TFII acts as a tumor promoter by enhancing invasion and metastasis (9-11). However, several reports suggest that COUP-TFII acts as a tumor suppressor via inhibition of cell proliferation and invasion $(12,13)$. We have previously 

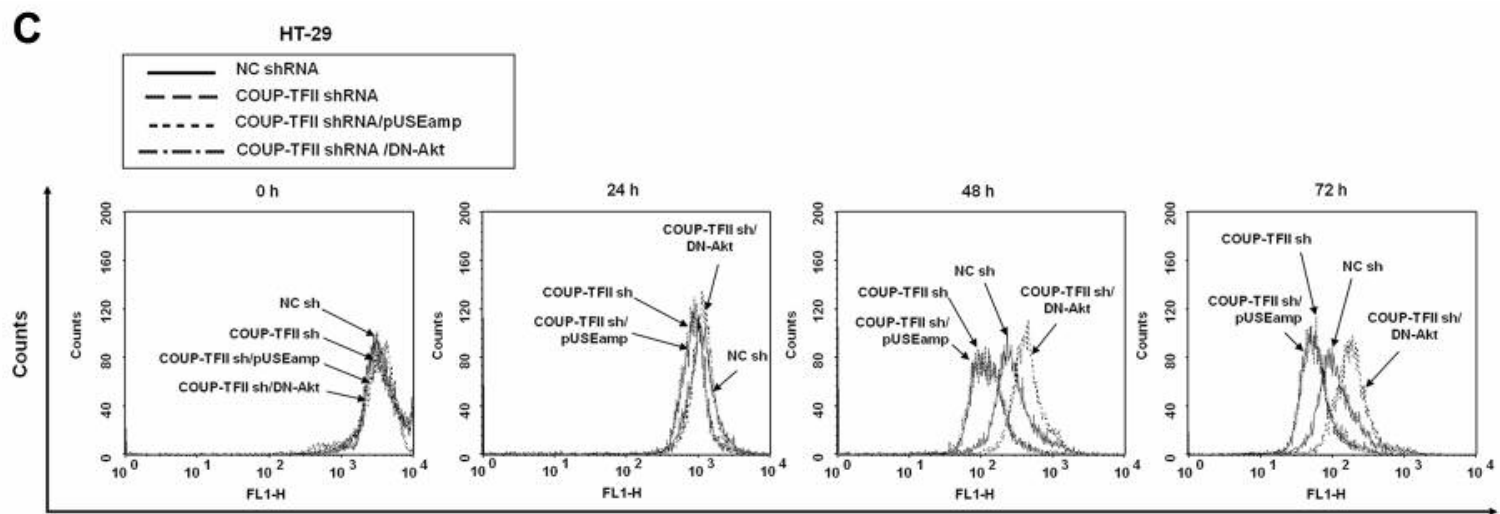

CFSE
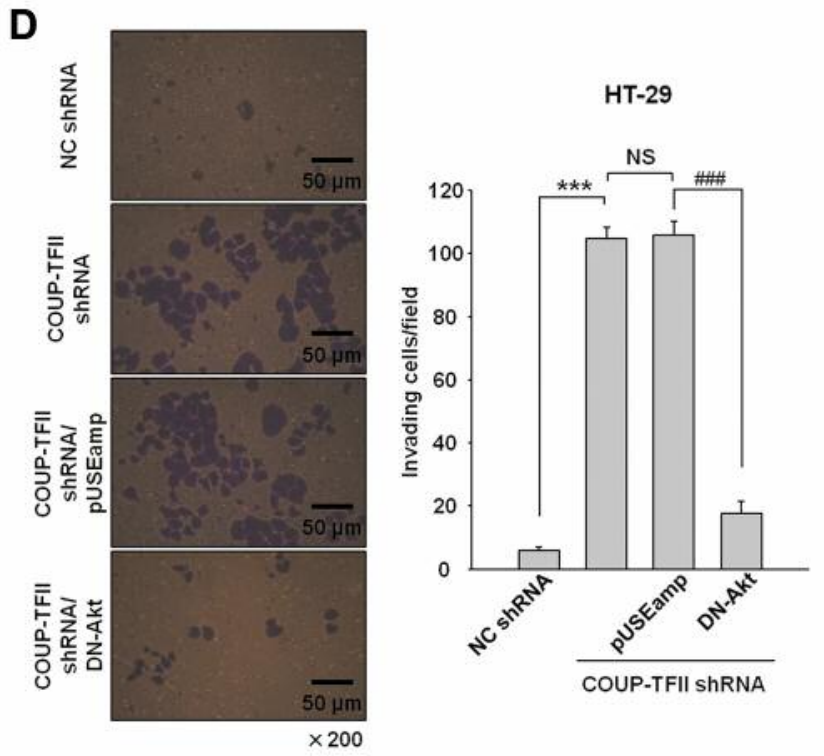

E

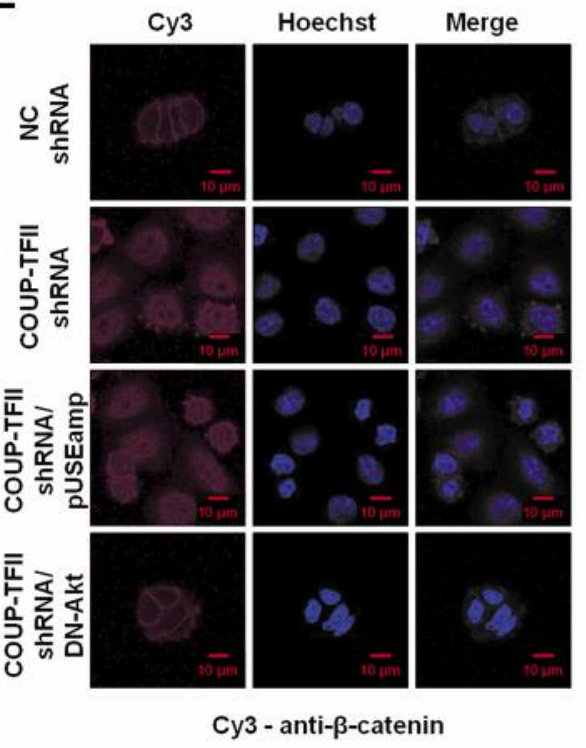

Figure 6. Dominant negative-Akt (DN-Akt) transfection reversed the increased cell proliferation and invasion induced by chicken ovalbumin upstream promoter-transcription factor II (COUP-TFII) knock-down. (A) COUP-TFII shRNA-HT-29 cells were transiently transfected by lipofectamine 2000 for $48 \mathrm{~h}$ with an empty vector pUSEamp or a DN-Akt expression vector. After transfection, protein lysates were prepared and used for western blot analysis with the corresponding antibodies. $\beta$-Actin was used as a loading control. The blot is representative of three separate experiments. Densitometry results (above each lane) were expressed relative to the non-targeting control (NC) shRNA group, after normalization to loading control $\beta$-actin. (B) DN-Akt transfection reversed the increased cell proliferation in COUP-TFII shRNA-HT-29 cells, as shown by the cell counting assay. ${ }^{*} p<0.05$, ***p<0.001 vs. NC shRNA-HT-29 cells; ${ }^{*}{ }^{*} p<0.001 \mathrm{vs.}$. COUP-TFII shRNA-HT-29 cells. (C) These results were also confirmed by the CFSE proliferation assay. (D) DN-Akt reversed the enhanced cell invasion by COUP-TFII knock-down. *** $<<0.001$ vs. NC sRNA-HT-29 cells;

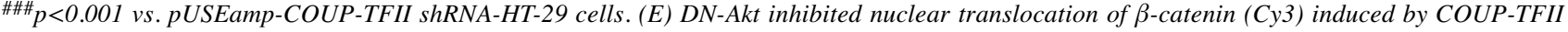
knock-down. Cell nuclei were stained by Hoechst dye. The results are representative of three separate experiments.

demonstrated that COUP-TFII might be a good prognostic indicator in CRC patients $(14,15)$. Herein, we examined the effect of COUP-TFII knock-down on cell proliferation, migration, and invasion by using stably knocked-down COUP-TFII shRNA-HT-29 cells. COUP-TFII shRNA-HT29 cells were shown to have increased colorectal cancer cell proliferation, migration, and invasion compared to the NC control cells. These results are similar to Wang's study (13), which suggested that COUP-TFII knock-down promotes cell proliferation, migration and invasion of normal gastric mucosa cells (GES-1), even though a different cell line was used. 
Invasion and metastasis are characteristics of malignant cancers (38). EMT promotes cancer cell migration and invasion (39). In the preset study, we found that COUP-TFII knock-down resulted in a reduced expression of E-cadherin (epithelial marker) and increased expression of $\mathrm{N}$-cadherin and vimentin (mesenchymal markers), contributing to enhanced migration and invasion of COUP-TFII shRNA-HT29 cells. To investigate the molecular mechanism underlying the enhanced cell proliferation, migration, and invasion induced by COUP-TFII knock-down, microarray analysis was performed. Microarray analysis results revealed that many genes were up- or down-regulated. Among them, we focused on two genes, FOXC1 and MMP7, due to their implication in EMT and cell invasion $(17,20)$. The results showed that FOXC1 and MMP7 were up-regulated in COUP-TFII shRNA-HT-29 cells compared to NC shRNA-HT-29 cells. The increased expression levels of FOXC1 and MMP7 in COUP-TFII shRNA-HT-29 cells were also confirmed by western blot analysis. Since MMP7 has been shown to act as a downstream effector in FOXC1-induced invasion (20), it is suggested that the levels of FOXC1 and MMP7 may be regulated by COUP-TFII knock-down due to enhanced invasion. However, the detailed molecular mechanism remains unclear and further mechanistic studies are needed.

Accumulating evidence suggests that FOXC1 induces EMT, resulting in enhanced invasion $(40,41)$. Especially, FOXC1 has been shown to enhance proliferation and EMT of cervical cancer via Akt activation (42). Based on this previous observation (42), we analyzed the role of Akt/GSK$3 \beta / \beta$-catenin pathway in enhanced cell proliferation and invasion induced by COUP-TFII knock-down. It was demonstrated that $\mathrm{p}$-Akt, $\mathrm{p}$-GSK-3 $\beta$, and $\beta$-catenin levels were significantly increased in COUP-TFII shRNA-HT-29 cells, compared to NC shRNA-HT-29 cells. Moreover, nuclear translocation of $\beta$-catenin was observed, which resulted in increased expression of c-Myc, cyclin D1, vimentin, and N-cadherin in COUP-TFII shRNA-HT-29 cells. The relationship between FOXC1 and $\beta$-catenin has been already reported $(37,43)$. Specifically, one study demonstrated that $\beta$-catenin can directly regulate the transcription of FOXC1 (37), while another showed that FOXC1 regulates $\beta$-catenin by binding to the $\beta$-catenin promoter (43). However, in the present study, we did not evaluate whether the activation of $\beta$-catenin and the upregulation of FOXC1 are required for enhanced proliferation and invasion by COUP-TFII knock-down in HT-29 cells. Thus, further studies are needed to explore the regulatory network associated with FOXC1 and $\beta$-catenin.

To further investigate whether activation of Akt (increased p-Akt expression) is required for enhanced cell proliferation and invasion by COUP-TFII knock-down, NC shRNA-HT29 and COUP-TFII shRNA-HT-29 cells were treated with Akt inhibitor IV, and the cell proliferation and invasion were determined. The results demonstrated that Akt inhibitor IV significantly reversed the COUP-TFII knock-down-induced enhanced proliferation and invasion. In addition, similar results were shown by DN-Akt transfection, while the reversal of COUP-TFII-induced effects accompanied by inhibition of nuclear translocation of $\beta$-catenin and decreased expression of FOXC1 and MMP7. These results indicated that Akt acts upstream of FOXC1 and MMP7 expression, which is contrary to a previous finding (42). Further studies are needed to examine the role of FOXC1 in enhanced cell proliferation and invasion by COUP-TFII knock-down. Taken together, these data suggest that increased Akt activity is required for the enhanced cell proliferation and invasion observed in COUP-TFII shRNA-HT-29 cells.

\section{Conclusion}

This study is the first to demonstrate that COUP-TFII knockdown enhances colorectal cancer cell proliferation and invasion via activation of the Akt pathway and up-regulation of FOXC1. Hence, our data suggested that COUP-TFII may have a tumor suppressive effect through the inhibition of Akt pathway in CRC patients. Further investigations to elucidate the molecular crosstalk between FOXC1 and $\beta$-catenin, as well as the effect of COUP-TFII knock-down in vivo may reveal novel targets for the treatment of metastatic colorectal cancer.

\section{Conflicts of Interest}

The Authors declare that they have no conflicts of interest.

\section{Authors' Contributions}

SHY and SHH conducted all the experiments and drafted the manuscript under the supervision of JIP. JIP conceived the idea for this study, interpreted the results of experiments and wrote the manuscript. All Authors discussed the results and reviewed the manuscript prior to submission.

\section{Acknowledgements}

The present study was supported by the Basic Science Research Program through the National Research Foundation of Korea (NRF) funded by the Ministry of Science, ICT \& Future Planning (NRF2017R1A2B4011428, 2019R1F1A1059895).

\section{References}

1 Siegel R, Ma J, Zou Z and Jemal A: Cancer statistics, 2014. CA Cancer J Clin 64(1): 9-29, 2014. PMID: 24399786. DOI: 10.3322/caac. 21208

2 Zeuner A, Todaro M, Stassi G and De Maria R: Colorectal cancer stem cells: from the crypt to the clinic. Cell Stem Cell 15(6): 692-705, 2014. PMID: 25479747. DOI: 10.1016/ j.stem.2014.11.012 
3 Sung JJ, Lau JY, Young GP, Sano Y, Chiu HM, Byeon JS, Yeoh KG, Goh KL, Sollano J, Rerknimitr R, Matsuda T, Wu KC, Ng S, Leung SY, Makharia G, Chong VH, Ho KY, Brooks D, Lieberman DA and Chan FK: Asia Pacific consensus recommendations for colorectal cancer screening. Gut 57(8): 1166-1176, 2008. PMID: 18628378. DOI: 10.1136/gut.2007.146316

4 Byeon JS, Yang SK, Kim TI, Kim WH, Lau JY, Leung WK, Fujita R, Makharia GK, Abdullah M, Hilmi I, Sollano J, Yeoh KG, Wu DC, Chen MH, Kongkam P and Sung JJ: Colorectal neoplasm in asymptomatic Asians: a prospective multinational multicenter colonoscopy survey. Gastrointest Endosc 65(7): 1015-1022, 2007. PMID: 17531636. DOI: 10.1016/j.gie. 2006.12.065

5 Guan X: Cancer metastases: challenges and opportunities. Acta Pharm Sin B 5(5): 402-418, 2015. PMID: 26579471. DOI: 10.1016/j.apsb.2015.07.005

6 Dienstmann R, Vermeulen L, Guinney J, Kopetz S, Tejpar S and Tabernero J: Consensus molecular subtypes and the evolution of precision medicine in colorectal cancer. Nat Rev Cancer 17(4): 79-92, 2017. PMID: 28050011. DOI: 10.1038/nrc.2016.126

7 Wang LH, Tsai SY, Cook RG, Beattie WG, Tsai MJ and O'Malley BW: COUP transcription factor is a member of the steroid receptor superfamily. Nature 340(6229): 163-166, 1989. PMID: 2739739. DOI: $10.1038 / 340163 \mathrm{a} 0$

8 Lee MN, Kim JW, Oh SH, Jeong BC, Hwang YC and Koh JT: FGF2 stimulates COUP-TFII expression via the MEK1/2 pathway to inhibit osteoblast differentiation in C3H10T1/2 cells. PLoS One 11(7): e0159234, 2016. PMID: 27404388. DOI: 10.1371/journal.pone. 0159234

9 Qin J, Tsai SY and Tsai MJ: The critical roles of COUP-TFII in tumor progression and metastasis. Cell Biosci 4(1): 58, 2014. PMID: 25328664. DOI: 10.1186/2045-3701-4-58

10 Navab R, Gonzalez-Santos JM, Johnston MR, Liu J, Brodt P, Tsao MS and Hu J: Expression of chicken ovalbumin upstream promoter-transcription factor II enhances invasiveness of human lung carcinoma cells. Cancer Res 64(15): 5097-5105, 2004. PMID: 15289311. DOI: 10.1158/0008-5472.CAN-03-1185

11 Polvani S, Tarocchi M, Tempesti S, Mello T, Ceni E, Buccoliero F, D'Amico M, Boddi V, Farsi M, Nesi S, Nesi G, Milani S and Galli A: COUP-TFII in pancreatic adenocarcinoma: clinical implication for patient survival and tumor progression. Int $\mathrm{J}$ Cancer 134(7): 1648-1658, 2014. PMID: 24122412. DOI: $10.1002 / \mathrm{ijc} .28502$

12 Nakshatri H, Mendonca MS, Bhat-Nakshatri P, Patel NM, Goulet RJ Jr and Cornetta K: The orphan receptor COUP-TFII regulates $\mathrm{G} 2 / \mathrm{M}$ progression of breast cancer cells by modulating the expression/activity of p21(WAF1/CIP1), cyclin D1, and cdk2. Biochem Biophys Res Commun 270(3): 1144-1153, 2000. PMID: 10772965. DOI: 10.1006/bbrc.2000.2562

13 Ding W, Zhang Y, Cai H, Liu G, Ye Y, Xu G, Wang H, Xiong D, Zhang C, Huang Z and Luo Q: Overexpression of COUPTFII suppresses proliferation and metastasis of human gastric cancer cells. Mol Med Rep 17(2): 2393-2401, 2018. PMID: 29207189. DOI: $10.3892 / \mathrm{mmr} .2017 .8164$

14 Shin SW, Kwon HC, Rho MS, Choi HJ, Kwak JY and Park JI: Clinical significance of chicken ovalbumin upstream promotertranscription factor II expression in human colorectal cancer. Oncol Rep 21(1): 101-106, 2009. PMID: 19082449.

15 Yun SH, Park MG, Kim YM, Roh MS and Park JI: Expression of chicken ovalbumin upstream promoter-transcription factor II and liver $\mathrm{X}$ receptor as prognostic indicators for human colorectal cancer. Oncol Lett 14(4): 4011-4020, 2017. PMID: 28943908. DOI: $10.3892 /$ ol.2017.6659

16 Yang Z, Jiang S, Cheng Y, Li T, Hu W, Ma Z, Chen F and Yang Y: FOXC1 in cancer development and therapy: deciphering its emerging and divergent roles. Ther Adv Med Oncol 9(12): 797-816, 2017. PMID: 29449899. DOI: $10.1177 / 1758834017742576$

17 Cao S, Wang Z, Gao X, He W, Cai Y, Chen H and Xu R: FOXC1 induces cancer stem cell-like properties through upregulation of beta-catenin in NSCLC. J Exp Clin Cancer Res 37(1): 220, 2018. PMID: 30189871. DOI: 10.1186/s13046-0180894-0

18 Han B, Zhou B, Qu Y, Gao B, Xu Y, Chung S, Tanaka H, Yang W, Giuliano AE and Cui X: FOXC1-induced non-canonical WNT5A-MMP7 signaling regulates invasiveness in triplenegative breast cancer. Oncogene 37(10): 1399-1408, 2018. PMID: 29249801. DOI: 10.1038/s41388-017-0021-2

19 Liu J, Zhang Z, Li X, Chen J, Wang G, Tian Z, Qian M, Chen Z, Guo H, Tang G, Huang W, Tian D, Wang D, Nie Y, Fan D, Wu K and Xia L: Forkhead box C1 promotes colorectal cancer metastasis through transactivating ITGA7 and FGFR4 expression. Oncogene 37(41): 5477-5491, 2018. PMID: 29884889. DOI: $10.1038 / \mathrm{s} 41388-018-0355-4$

20 Sizemore ST and Keri RA: The forkhead box transcription factor FOXC1 promotes breast cancer invasion by inducing matrix metalloprotease 7 (MMP7) expression. J Biol Chem 287(29): 24631-24640, 2012. PMID: 22645147. DOI: 10.1074/jbc. M112.375865

21 Sun DW, Zhang YY, Qi Y, Zhou XT and Lv GY: Prognostic significance of MMP-7 expression in colorectal cancer: a metaanalysis. Cancer Epidemiol 39(2): 135-142, 2015. PMID: 25677090. DOI: 10.1016/j.canep.2015.01.009

22 Rucci N, Sanità P and Angelucci A: Roles of metalloproteases in metastatic niche. Curr Mol Med 11(8): 609-622, 2011. PMID: 21707518. DOI: $10.2174 / 156652411797536705$

23 Yang B, Su K, Gao J and Rao Z: Expression and prognostic value of matrix metalloproteinase-7 in colorectal cancer. Asian Pac J Cancer Prev 13(3): 1049-1052, 2012. PMID: 22631636. DOI: 10.7314/apjcp.2012.13.3.1049

24 Fukuda A, Wang SC, Morris JP 4th, Folias AE, Liou A, Kim GE, Akira S, Boucher KM, Firpo MA, Mulvihill SJ and Hebrok M: Stat3 and MMP7 contribute to pancreatic ductal adenocarcinoma initiation and progression. Cancer Cell 19(4): 441-455, 2011. PMID: 21481787. DOI: 10.1016/j.ccr.2011.03.002

25 Ito TK, Ishii G, Saito S, Yano K, Hoshino A, Suzuki T and Ochiai A: Degradation of soluble VEGF receptor-1 by MMP-7 allows VEGF access to endothelial cells. Blood 113(10): 23632369, 2009. PMID: 18974372. DOI: 10.1182/blood-2008-08172742

26 Kioi M, Yamamoto K, Higashi S, Koshikawa N, Fujita K and Miyazaki K: Matrilysin (MMP-7) induces homotypic adhesion of human colon cancer cells and enhances their metastatic potential in nude mouse model. Oncogene 22(54): 8662-8670, 2003. PMID: 14647460. DOI: 10.1038/sj.onc.1207181

27 Shin SW, Yun SH, Park ES, Jeong JS, Kwak JY and Park JI: Overexpression of PGC-1 $\alpha$ enhances cell proliferation and tumorigenesis of HEK293 cells through the upregulation of Sp1 and Acyl-CoA binding protein. Int J Oncol 46(3): 1328-1342, 2015. PMID: 25585584. DOI: 10.3892/ijo.2015.2834 
28 Kang W, Nielsen O, Fenger C, Leslie G, Holmskov U and Reid KB: Induction of DMBT1 expression by reduced ERK activity during a gastric mucosa differentiation-like process and its association with human gastric cancer. Carcinogenesis 26(6): 1129-1137, 2005. PMID: 15760920. DOI: 10.1093/carcin/bgi045

29 Shin SW, Seo CY, Han H, Han JY, Jeong JS, Kwak JY and Park JI: $15 d-\mathrm{PGJ}_{2}$ induces apoptosis by reactive oxygen speciesmediated inactivation of Akt in leukemia and colorectal cancer cells and shows in vivo antitumor activity. Clin Cancer Res 15(17): 5414-5425, 2009. PMID: 19690198. DOI: 10.1158/10780432.CCR-08-3101

30 Steelman LS, Abrams SL, Whelan J, Bertrand FE, Ludwig DE, Bäsecke J, Libra M, Stivala F, Milella M, Tafuri A, Lunghi P, Bonati A, Martelli AM and McCubrey JA: Contributions of the Raf/MEK/ERK, PI3K/PTEB/Akt/mTOR and Jak/STAT pathways to leukemia. Leukemia 22(4): 686-707, 2008. PMID: 18337767. DOI: $10.1038 /$ leu.2008.26

31 Ye B, Jiang LL, Xu HT, Zhou DW and Li ZS: Expression of PI3K/Akt pathway in gastric cancer and its blockade suppresses tumor growth and metastasis. Int J Immunopathol Pharmacol 25(3): 627-636, 2012. PMID: 23058013. DOI: 10.1177/ 039463201202500309

$32 \mathrm{Xu} \mathrm{W}$, Yang Z and Lu N: A new role for the PI3K/Akt signaling pathway in the epithelial-mesenchymal transition. Cell Adh Migr 9(4): 317-324, 2015. PMID: 26241004. DOI: 10.1080/193369 18.2015.1016686

33 Hermida MA, Kumar JD and Leslie NR: GSK3 and its interactions with the PI3K/AKT/mTOR signaling network. Adv Biol Regul 65: 5-15, 2017. PMID: 28712664. DOI: 10.1016/ j.jbior.06.003

34 Pan J, Fan Z, Wang Z, Dai Q, Xiang Z, Yuan F, Yan M, Zhu Z, Liu $\mathrm{B}$ and $\mathrm{Li} \mathrm{C}$ : CD36 mediates palmitate acid-induced metastasis of gastric cancer via AKT/GSK-3 $\beta / \beta$-catenin pathway. J Exp Clin Cancer Res 38(1): 52, 2019. PMID: 30717785. DOI: 10.1186/s13046-019-1049-7

35 Yuan K, Xie K, Lan T, Xu L, Chen X, Li X, Liao M, Li J, Huang J, Zeng Y and Wu H: TXNDC12 promotes EMT and metastasis of hepatocellular carcinoma cells via activation of $\beta$ catenin. Cell Death Differ, 2019. PMID: 31570854. DOI: 10.1038/s41418-019-0421-7

36 Morris SL and Huang S: Crosstalk of the Wnt/ $\beta$-catenin pathway with other pathways in cancer cells. Genes Dis 3(1): 41-47, 2016. PMID: 27081668. DOI: 10.1016/j.gendis.2015.12.003
37 Savage J, Voronova A, Mehta V, Sendi-Mukasa F and Skerjanc IS: Canonical Wnt signaling regulates Foxc $1 / 2$ expression in P19 cells. Differentiation 79(1): 31-40, 2010. PMID: 19782461. DOI: 10.1016/j.diff.2009.08.008

38 Woodhouse EC, Chuaqui RF and Liotta LA: General mechanisms of metastasis. Cancer 80(8): 1529-1537, 1997. PMID: 9362419. DOI: 10.1002/(sici)1097-0142(19971015)80:8+<1529::aid-cncr2 $>3.3 . \mathrm{co} ; 2-\#$

39 Thiery JP, Acloque H, Huang RY and Nieto MA: Epithelialmesenchymal transitions in development and disease. Cell 139(5): 871-890, 2009. PMID: 19945376. DOI: 10.1016/j.cell.2009.11.007

40 Ray PS, Wang J, Qu Y, Sim MS, Shamonki J, Bagaria SP, Ye X, Liu B, Elashoff D, Hoon DS, Walter MA, Martens JW, Richardson AL, Giuliano AE and Cui X: FOXC1 is a potential prognostic biomarker with functional significance in basal-like breast cancer. Cancer Res 70(10): 3870-3876. 2010. PMID: 20406990. DOI: 10.1158/0008-5472.CAN-09-4120

41 Bloushtain-Qimron N, Yao J, Snyder EL, Shipitsin M, Campbell LL, Mani SA, Hu M, Chen H, Ustyansky V, Antosiewicz JE, Argani P, Halushka MK, Thomson JA, Pharoah P, Porgador A, Sukumar S, Parsons R, Richardson AL, Stampfer MR, Gelman RS, Nikolskaya T, Nikolsky Y and Polyak K: Cell type-specific DNA methylation patterns in the human breast. Proc Natl Acad Sci USA 105(37): 14076-14081, 2008. PMID: 18780791. DOI: 10.1073/pnas.0805206105

42 Huang L, Huang Z, Fan Y, He L, Ye M, Shi K, Ji B, Huang J, Wang Y and Li Q: FOXC1 promotes proliferation and epithelialmesenchymal transition in cervical carcinoma through the PI3KAKT signal pathway. Am J Transl Res 9(3): 1297-1306, 2017. PMID: 28386355.

43 Cao Q, Wang X, Shi Y, Zhang M, Yang J, Dong M, Mi Y, Zhang $\mathrm{Z}$, Liu K, Jiang L, Wang $\mathrm{N}$ and Wang P: FOXC1 silencing inhibits the epithelial-to-mesenchymal transition of glioma cells: Involvement of $\beta$-catenin signaling. Mol Med Rep 19(1): 251261, 2018. PMID: 30431099. DOI: 10.3892/mmr.2018.9650

Received November 1, 2019

Revised November 27, 2019

Accepted December 2, 2019 